\title{
POSSIBILITIES OF RURAL TOURISM DEVELOPMENT IN THE AREA OF THE MUNICIPALITY OF TRSTENIK
}

\section{Jelena Bićanin ${ }^{1}$}

\section{Summary}

Favourable geographical position of municipality of Trstenik, which is located in a fertile valley of the West Morava river, would enable the local people to deal with rural tourism which lacks attention despite potentially positive effects which would be created due to its development. The primary aim of this research paper was the insight into the potentials of the municipality, which would contribute to a rural tourism development. The research was performed during the period from July 20 to September 2 of 2017 on a sample of 138 respondents. For the research purposes the following methods were available: quantitative approach by questioning public opinion via questionnaires close-ended and anonymous type, method of analysis, method of sample, as well as method of description. The results of the research showed the following: the territory of this municipality possesses potential for rural tourism development despite deficiency of accomodation facilities and insufficient motivation of the local people to deal with tourism, whereas social networks could contribute to its promotion and development. The limit of the research paper is reflected in a small extent of the target group of respondents, which leaves the possibility for widening of research outside the boundaries of the territory of this municipality.

Key words: rural tourism, Trstenik, potentials, promotion, social networks

JEL: Z32

\section{Introduction}

Since the moment when its first forms appeared till today, tourism has passed through many stages of its development. The necessity of the emergence of various forms of tourism, with the aim to satisfy all affinities of different segments of tourist demands, indicates its importance which has increased during the time. Rural tourism has distinguished itself as the specific form of tourism. In the 19th century people noticed rural areas as those which possess valuable elements to attract tourist attention. That's

1 Jelena Bićanin, Ph.D. Student, University of Kragujevac, Faculty of Hotel Management and Tourism, Vojvođanska Street, 36210 Vrnjci Spa, Serbia, Telephone: +381 616809713 , E-mail: jelenabicanin9@,gmail.com

EP 2018 (65) 1 (355-372) 
the reason why the special attention was paid to the rural tourism development in rural areas of the European countries during the 1970s. Then it became some kind of organized economic activity, in which many countries saw the solution to some important problems such as: migration of young people to urban areas, deficiency of various activities and underdevelopment of rural areas (Milenković, Utvić, 2013).

Therefore,tourism starts to be considered as a way to enhance and renew the rural areas, that is the rural community. The focus is gradually shifting from rural area as an area in which people are exclusively dealing with agricultural production to the insight into additional possibilities that this area gives. According to Cavaye (2001), when we talk about rural community development, we think on its entire development, not only from the aspect of economic progress. Through many different activities which tourism brings in the rural area, the vitality of the community which exists in the rural area can be achieved. Authors such as Čikić, Jovanović (2015) are adducing that for rural tourism development a rural area itself is insufficient. That area must have sufficient quality resources for tourism activity realization. The territory of the municipality of Trstenik, from the aspect of natural and anthropogenic potentials, leaves the possibility of rural tourism development. The idea of rural tourism in the territory of this municipality comes from its ability to alleviate the problems almost all rural areas (among others also those in this part of Serbia) are faced with and to lead to rural development. However, the question is: Would rural tourism contribute to rural development in the territory of this municipality? The answer depends on degree of motivation of local community to deal with this activity, on its ability to use available resources in the right way for the necessities of tourism and to create attractive tourist offer.

The aim of this research paper is to determine if the territory of the municipality of Trstenik has the potentials for rural tourism development, which, besides agriculture activity as the dominant in rural areas of this municipality, would contribute to the improvement of current state from the aspect of living standard of local population. Development of tourism activity in rural areas of this municipality would mean the employment of new workers with the aim of satisfying potential tourists' needs, as well as the incentive for young people to direct their knowledge and creativity towards this process through their staying in the countryside. Through the insight into the current state in rural areas, rural tourism and limiting factors for its development in this part of Serbia, as well as the role of social networks in its promotion, the possibilities for development of this type of tourism will be thus considered.

\section{Review of literature}

Many authors have dealt with the topic of rural tourism from different aspects. According to tendencies of 'Tourism Development Strategy of the Republic of Serbia for the Period from 2016 to 2025' ('Official Gazette of RS', 2016), the document whose author is the Government of the Republic of Serbia, rural tourism in Serbia could become an activity people from the rural areas will deal with, which points to the fact that it holds the sixth place on the list of most demanded tourism products. This 
encouraged the author of this research paper to deal with the topic of rural tourism by adducing those authors who are greatly dealing with the same topic.

Cavaye (2001) is talking primarily about empowerment of local community which should provide development of rural area and then also a realization of rural tourism. It is about an empowerment of community through ongoing economic, social and environmental progress. The concept of empowerment of local communities in the territory of the municipality of Trstenik for this municipality would mean the possibility for realization of rural tourism as an activity which is, according to Čikić, Jovanović (2015), more than ordinary spending time in rural area for tourists and more than getting money for local people who deal with it.

Maksin (2012) highlights the space as initial resource which gives an opportunity to a certain rural area to realize rural tourism. With respect to this, from the aspect of theoretical determination of rural area in Serbia and percentages which are recorded in the context of territory and the population of the inhabitants, Cvijanović, Ružić (2017) have dealt with this topic. The area itself doesn't give the possibility for development of this type of activity if some preconditions are not fulfilled. Todorović, Stetić (2009) give the review of activities that should be available to potential tourists in the certain destination of rural area in order to meaningfully fulfill the time during their stay. With the concept of sustainable development, with the help of which conservation of natural and anthropogenic resources can be achieved, were dealing Maksin, Pucar, Korać, Milijić (2009), and that attractiveness of these resources is important precondition and motivation for destination choice is also confirmed by Vojnović, Cvijanović, Stefanović (2012). Rosić, Popesku (1999) are talking about possibilities for rural tourism development from the aspect of provision of transport infrastructure, funds and necessity of services' standardization and categorization.

The authors such as Đorđević-Milošević, Milovanović (2012) have dealt with the specific problems that rural areas in Serbia are faced with, pointing out that agriculture development should not be equated with development of rural areas and rural tourism, as well as Đukić, Glavaš-Trbić, Banjac (2017) by focusing their attention on the problems of depopulation and senilization on Fruška gora.

In tourism, as well as in other activities, it is necessary to create such an offer which will surpass competitors' offer and to be presented in the best possible way. According to Cvijanović, Mihailović, Vukotić (2016), both an offer and a marketing should be created as authentic as possible. It is considered that the internet and social networks would significantly contribute to this field. The researches which have been carried out by Stojković (2013), but also by foreign authors such as Saravanakumar, SuganthaLakshmi (2012), Stelzner (2016), as well as Okazaki, Andreu, Campo (2016) confirm this fact.

\section{Methodological framework}

During the research process the author used those scientific research methods which would respond to object and aim of this research paper and bring relevant data: method 
of questioning public opinion for gathering informations, method of analysis applied for observation and separation of essential characteristics, method of sample for identifying target groups which will participate in a research, as well as methods from the domain of descriptive statistics for graphic view and description of collected data.

The process of gathering informations has been achieved through two questionnaires which are characterized as close-ended and anonymous type which is quantitative approach to research. The author of this research paper chose that type of questioning public opinion in order to get responses as objective as possible. Adults from the territory of the municipality of Trstenik took part in the research process, which belongs to the domain of sampling method. The first questionnaire, which was structured so as to explore the state and the perspectives of rural tourism development on the territory of the municipality of Trstenik, included 22 questions and 87 respondents. The set of the first ten questions, which belong to this questionnaire, was created so that gives basic demographic information about respondents (gender, age, educational structure, place of living from the aspect of rural and urban areas, frequency of visiting rural areas by respondents who live in urban area, time spent in the countyside during the visit, as well as reasons for visiting countryside). The following three questions pertain to the familiarity of respondents with the situation of rural areas on the territory of this municipality. The remaining questions (nine questions) explore the attitudes about possibilities for current and future rural tourism development. The other questionnaire, created to explore the extent of social networking sites usage, as well as the impact of social networks on rural tourism promotion, included 17 questions and 51 respondents. The necessity of creating other questionnaire arose as result of literature analysis, which was used during the research process for this research paper and which indicated clearly that social networks contribute significantly in a domain of certain product promotion, in this case tourism product promotion and therefore leads to the increase in number of potentially interested clients. Whereas the aim of this research paper is focused on insight into the possibilities for rural tourism development on the territory of the municipality of Trstenik, the research included also potential impact of social networks which would contribute to its development. This questionnaire gives first of all basic demographic information about respondents, then attitudes about Internet usage and finally attitudes about social networks usage and their importance in the field of tourism. Collected data were analyzed, as well as presented in a form of tables and graphs. The research was performed during the period from July 20 to September 2 of 2017.

\section{Rural tourism and preconditions for its development}

Initial resource, as an important precondition for rural tourism development, is the surrounding area. According to Maksin (2012), it is about a complex system. What does that complexity reflect on? It reflects on the existence of numerous subsystems, which compose the area and which are caracterized by relation of interconnection and conditionality: natural, economic, social, technical, infrastructural and political. With the same approach to the surroundings many authors such as Ambrosio-Albalá, 
Bastiaensen (2010) were also dealing by adducing the following: 'In a wider sense, a rural territory can be conceived as a social-ecological system shaped by both social and ecological subsystems in interaction'. In the context of rural tourism, we talk about the rural area as the specific space for development of this type of tourism. The theoretical determination of rural area has been given by many of the authors and, among others, by the Organization for Economic Co-operation and Development (OECD). All of them have agreed in one thing: rural area is the area with a population density below 150 people per square kilometer. This theoretical description of rural area has been complemented with its participation percentage in total area of the certain territory, which is $85 \%$, as well as participation percentage of rural population of $55,5 \%$. The participation percentage of territorial rurality in Serbia is a bit less, it amounts to $70 \%$ and on the total area there is $43 \%$ of total population (Cvijanović, Ružić, 2017).

The necessity for rural tourism appeared as the result of man's confrontation with the features of the modern period. Rural tourism is cosidered to be as a specific type of tourism, which comprises 'all activities in rural area and which is caracterized by quite environment, preserved natural environment, absence of noise, communication with householders, domestic food and getting acquainted with rural jobs' (Štetić, Šimičević, Ćurčić, 2013). What attracts tourists to spend and direct their leisure time towards the nature and the way of living which differs significantly from the everyday lifestyle? The answers should be sought in man's desire to imrove the quality of his life by getting in touch with a healthy environment and acquiring healthy lifestyle habits. When we talk about these habits, we mean resting and recreation in a healthy environment which is presented by various activities: tours (walking, mountaineering, horse riding, ecotours), water activities (swimming, fishing, diving, rafting), aerial activities (paragliding, flying with balloon), sport activities (golf, tennis, skiing), cultural activities (archeology, folklore and gastronomy courses) and many other (Todorović, Štetić, 2009). Tsai (2016) is adding one more element which completes the certain tourist destination experience. It is about local food which is offered to tourists within the entire tourist offer. He considers that this element provides an unforgettable experience to tourists because it implies an involvement of many senses in its consummation. Furthermore, he is adding that this element is recognized as very important because in its promotion many travelling TV programmes, magazines, books are participating increasingly, as well as social networks where tourists excange their experiences.

However, in order for this kind of tourism to be fully realized and developed in certain area, it is necessary for rural tourism to fulfill the appropriate preconditions. The first one on the list of preconditions is a concept of sustainable tourism development. The devotion to this concept was started in 1987 by the World Commission of the United Nations on Environment and Development with the publishing of the document 'Our Common Future'. Sustainable tourism development implies activities which are directed towards a provision of life and environmental quality, raising awareness of available resource usage, as well as awareness of equal territorial development. The fulfilment of these factors would contribute a conservation of natural and anthropogenic resources from the aspect of 
three criteria: economic, social and environmental (Maksin, Pucar, Korać, Milijić, 2009). The rural tourism development also depends on the resources which exist in a certain destination and whose attractiveness would contribute to the development. The resources are divided into the natural (climate, hydrographic potential, relief, flora and fauna) and the anthropogenic (cultural and historical elements). All of these resources affect the potential tourists' perception of travel destination quality, the state which as result has creation of its long-term image (Vojnović, Cvijanović, Stefanović, 2012). Rosić and Popesku (1999) have also added transport infrastructure development, provision of funds, as well as services' standardization and categorization to this list of preconditions. All of the above-mentioned preconditions, however, are insufficient for the realization of rural tourism if local people are not motivated to deal with this type of tourism activity. This has been also confirmed by Markov (2006), who has adduced the motivation as the leading factor. He adds that the absence of this precondition often turns into a limiting factor of rural tourism development. Finally, Valrabenštajn (2007) is talking about the tourist product image and brand, which affect its quality and tourist product increase. Furthermore, he adds that by branding, as the kind of tool in the field of marketing and management, the authenticity of a product can be achieved, which plays an important role in its image-building.

\section{Rural tourism in Serbia and limiting factors of its development}

In the context of rural tourism and within the European borders, Serbia could significantly contibute to its development. It is considered that rural areas possess diversity of natural and anthropogenic potentials and agriculture is seen as the leading activity that people deal with. However, the problem arises in the moment when people equalize agricultural development with development of rural areas. Agriculture development doesn't signify necessarily development of rural areas, as indicated by high unemployment rate and migration of young population to towns (Đorđević-Milošević, Milovanović, 2012). Đukić, Glavaš-Trbić and Banjac (2017), using the example of Fruška gora as the area which settlements are mainly rural, adduce limiting factors for rural tourism development. Altough the area of Fruška gora is protected and as such suitable for development of agriculture production, it is faced with problems of depopulation and senilization. As the solutions for rural tourism development, these authors adduce that, except for agriculture, provision of appropriate rural infrastructure should be also included, as well as development of other activities which would become the source of income for local people. According to 'Tourism Development Strategy of the Republic of Serbia for the Period from 2016 to 2025', which has been adopted by the Government of the Republic of Serbia in November 2016, the rural tourism took 6th place on the list of most demanded tourism products in Serbia ('Official Gazette of RS', 2016). In this document certain tendencies have also been adduced which are expected to be fully realized over the foreseen period in rural tourism domain: vacation which implies getting in touch with village spirit, glamping tourism, visiting cultural and historical landmarks, trips with the gastronomic offer.

According to the above-mentioned document of the Government of the Republic of Serbia, rural areas in Serbia, among others, also those who belong to the territory of 
the municipality of Trstenik, are faced with problems which are seen as limiting factors for (rural) tourism development. Here are some of these problems: local people are not motivated to deal with rural tourism, young population is moving to towns, transport infrastructure is underdeveloped, the standard of living is low and the territory of the municipality doesn't have sufficiently accomodation facilities for the necessities of rural tourism. Insight into the potential effects from rural tourism development is a step towards its realization. According to Njegovan (2016), in the context of rural tourism we can talk about its positive and negative effects. Positive effects, seen as a whole, are reflected by an increase of living standards in rural areas: employee engagement, reducing of the unemployment rate, raising awareness of environmental protection, revenue realization from the agriculture, but also the rural tourism related activities. However, if an appropriate strategy of rural tourism development has not been created at the beginnig, negative effects gradually occur: intensive assimilation of local people with tourists could cause the loss of village authenticity, uncontrolled exploitation of natural resources causes biodiversity disruption, whereas rapid increase in the number of tourists could result in an inability of local people to respond to tourists' needs. Therefore, something that would enable the municipality of Trstenik to develop rural tourism is the creation of an appropriate strategy, which implies: insight into all the potentials, creating of counseling centers for local people with the aim of their encouragement to categorize households for the necessities of tourism, facing the problem of underdeveloped transport infrastructure, designing educational programs, more intensive involvement of local authorities and tourism organization as the support to the local population, as well as tourist offer promotion by using diverse promotional material and social networks (Škorić, 2013). Beyond these elements, the strategy would involve also the investigation of potential tourists' needs and motives. McKercher (2016), who has dealt with a research from a domain of attractivenesses as a motive for taking a trip, stated that the attractiveness of the certain destination is closely related to the nature of tourists' needs. Thus, he considers that attrastivenesses should be viewed from two aspects: as attractions, which include individual elements (monuments, buildings, natural phenomena) and as cultural heritage, which implies a set of cultural and historical elements. Therefore, an offer should be created by relying on these two aspects. Something that is not represented in our tourism industry and that, according to Sheenan, Vargas-Sanchez, Presenza, Abbate (2016), would lead to sustainable and competitive development of tourist destination is opening of Destination Management Organizations (DMOs). Under their jurisdiction are activities which include different sectors of tourism industry, among others also the coordination of relations between supply and demand.

\section{Rural tourism and social networks}

In order for tourists to recognize the potentials of some tourist offer and to satisfy their needs, it is necessary for the offer to be presented in the best possible way. Cvijanović, Mihailović and Vukotić (2016) are adducing the following fact: 'From the aspect of marketing, tourism is in the process of maturity which is caracterized by the saturation with existing methods of meeting needs'. This means that something new 
and authentic should be offered to tourists. However, except the offer, the authenticity should be also noticed in the way of its presenting. Changes that 'hit' tourism have also affected marketing, something that had been especially noticed in the second half of the 20 th century, more precisely in the 1970s. Then the importance of service sector was perceived; therefore, marketing has also included it. Its success has been reflected by its ability to outperform the service that competitor offers.

The changes have been caused by the globalization process, which, except the improvement of transport and means of transport, implies also the use of ICT (information and communication technologies), which gains a competetive advantage in the marketplace (Damnjanović, Petronić-Petrović, Tešić, Urošević, 2015). The special attention should be given to Internet and social networks. With Stojković (2013) we come across the information according to which the Internet usage for the purposes of tourism has been noticed in $80 \%$ of cases considered at a global level. A large part of that refers to social networks. The reason for this lies in the possibilities which social networks give to their users if they decide to present their offer through social networks: fast identifying of target group and directing attention to it, results of promotional activities are noticeable and their analysis can be carried out, whereas promotional activities include set of textual, visual and auditive elements. Saravanakumar and SuganthaLakshmi (2012) add that we can treat the Internet and social networks as achievements which, after Industrial Revolution, have a great importance for humanity. Their application can be seen in all the fields, whereas their potentials were recognized by big brands such as IBM (International Business Machines Corporation), Dell and Burger King. During the 2012 one fact was recorded according to which the percentage of companies which wanted to present their business activities to their consumers through social networks amounted to $39 \%$ and the tendencies in 2016 were indicating the percentage share of $47 \%$. The conducted researches for the necessities of this research paper indicate that in the field of tourism the following social networks stand out: Facebook, Instagram, Pinterest and Trip Advisor. With this part of research have been proven statements of the certain foreign authors, more precisely statements of Stelzner (2016), whose research points out Facebook as the social network to which $55 \%$ of entrepreneurs showed confidence, whereas $86 \%$ of them got access to ads and commercials by using it. The authors such as Okazaki, Andreu, Campo (2016) were doing researches in a domain of social networks, concretely Facebook and Trip Advisor and pointed out an increase of their popularity. From 2011 to 2015 Trip Advisor marked a significant increase in revenues, as well as an increase in a number of users of Trip Advisor mobile application, while over $60 \%$ of Americans make a decision about accomodation selection by using this service.

\section{Results and discussion}

Before we deal with the presentation of results, we should indicate some facts about how the results are divided. The first part refers on the presentation of current situation in rural areas within the municipality of Trstenik, the second one presents the current 
situation of rural tourism and the possibilities for its development in the future and the third one is dedicated to the analysis of social networks' influence in the field of rural tourism from the aspect of respondents' attitudes.

\section{Analysis of the current state in rural areas of the municipality of Trstenik}

In order to explore the state of rural tourism in area of this municipality, first of all we tried to perceive the situation in rural areas from the aspect of local people's attitudes. In Table 1 are presented basic demographic data of respondents.

Table 1. Demographic data of respondents (gender, age, place of living)

\begin{tabular}{|c|c|}
\hline \multicolumn{3}{|c|}{ Gender of respondents } \\
\hline Male: $49 \%$ & Female: $51 \%$ \\
\hline \multicolumn{3}{|c|}{ Age structure of respondents } \\
\hline $18-21$ & $9,2 \%$ \\
\hline $21-30$ & $44,8 \%$ \\
\hline $31-40$ & $18,4 \%$ \\
\hline $41-50$ & $9,2 \%$ \\
\hline $51-60$ & $14,9 \%$ \\
\hline over 60 & $3,9 \%$ \\
\hline & Place of respondents' living \\
\hline Rural area & $53 \%$ \\
\hline Urban area & $47 \%$ \\
\hline
\end{tabular}

Source: Results based on author's collected data

From $47 \%$ of respondents who live in urban area, $78 \%$ of them visit countryside. The main motive of their visit is not tourist visit to the countryside, but primarily visiting friends and relatives, as well as spending leisure time in their own house or cottage. When we talk about frequency of these departures, most of respondents go once a month $(36,6 \%)$, while $80,5 \%$ on that occasion stay no more than five days.

It was very important to investigate to what extent the respondents are familiar with the status of village, i.e. with the state of rural areas, as well as to investigate if and in what aspect they consider the rural areas to be developed or underdeveloped. Answers which were given by respondents show the following facts: $31 \%$ of respondents are completely informed about state of rural areas, 57,5\% of them are informed partially, and for $10,3 \%$ of them this topic is not attractive. From the aspect of development or underdevelopment, a large percentage of respondents consider these areas as underdeveloped, whereby they adduce a low living standard as the main reason, whereas a group of respondents with an opposite opinion observes development through available potential of rural areas so that people could deal also with those activities which are not agricultural (Graph 1). 
Graph 1. Respondents' attitudes from the aspect of development of rural areas of Trstenik

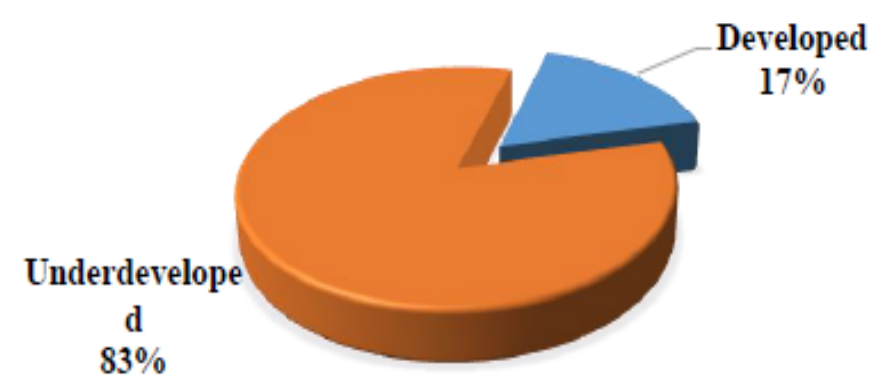

Source: Results based on author's collected data

\section{Analysis of possibilities for rural tourism development in the area of the municipality of Trstenik}

This analysis requires a complex approach to the topic because it implies a few elements which should be explored. What are those elements? First of all, it concerns attitudes of respondents about possibilities for the current rural tourism development (Graph 2), as well as about limiting factors for its development (Table 2). Results of the research about possibilities for the current rural tourism development indicate the positive attitude of respondents. In the total number of respondents, $65,5 \%$ consider that this activity could be developed currently. However, the group of respondents with an opposite opinion left open the possibility for the limiting factors of its development to be yet explored. The first on the list refers on insufficient involvement of local authorities in the process of rural tourism development. The other factors follow: the insufficient motivation of local people, lack of awareness about importance of rural tourism, deficiency of rural tourism households, lack of educational programs and bad transport infrastructure.

Graph 2. Could the rural tourism be developed currently in the area of the municipality of Trstenik?

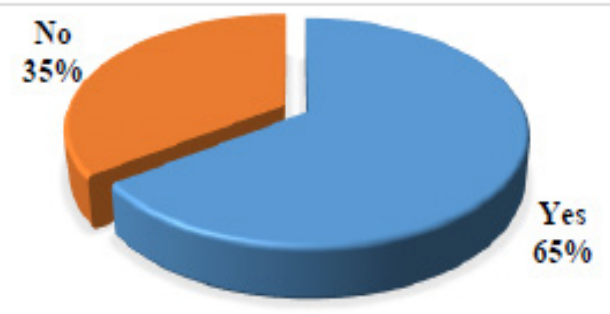

Source: Results based on author's collected data 
Table 2. Limiting factors for the current rural tourism development

\begin{tabular}{|l|c|}
\hline \multicolumn{1}{|c|}{ Limiting factors } & Percentage share of respondents \\
\hline Insufficient involvement of local authorities & $76,7 \%$ \\
\hline Insufficient motivation of local people & $73,3 \%$ \\
\hline $\begin{array}{l}\text { Lack of awareness about importance of rural } \\
\text { tourism }\end{array}$ & $70 \%$ \\
\hline Deficiency of rural tourism households & $56,7 \%$ \\
\hline Lack of educational programs & $50 \%$ \\
\hline Bad transport infrastructure & $46,7 \%$ \\
\hline Deficiency of natural and anthropogenic potentials & $6,7 \%$ \\
\hline Geographical position of the municipality & $3,3 \%$ \\
\hline
\end{tabular}

Source: Results based on author's collected data

Note: Respondents had a possibility to give more answers on this question

We must not neglect above mentioned limiting factors in spite of positive attitide of most respondents from the aspect of current rural tourism development. On the contrary, we should observe these factors as the current state which should be improved with the aim of rural tourism development. We should also add to these limiting factors the fact that local people are not informed about existence of rural households for the necessities of rural tourism. In the total number of respondents, $61 \%$ of them are not informed about this topic (Table 3). The reason for their not being well informed lies in the lack of these rural tourism households' promotion (Table 3).

Table 3. Views of informed respondents about existence of rural tourism households in the area of Trstenik and reasons why people are not informed about their existence

\begin{tabular}{|c|c|c|c|}
\hline \multicolumn{2}{|c|}{$\begin{array}{c}\text { Are you informed about existence of rural } \\
\text { tourism households in the area of Trstenik? }\end{array}$} & $\begin{array}{c}\text { What is the reason of your not being informed_- } \\
\text { about existence of these households? }\end{array}$ \\
\hline Yes & No & $\begin{array}{c}\text { Indifference for rural } \\
\text { tourism }\end{array}$ & $\begin{array}{c}\text { Lack of households' } \\
\text { promotion }\end{array}$ \\
\hline $39 \%$ & $61 \%$ & $15 \%$ & $85 \%$ \\
\hline
\end{tabular}

Source: Results based on author's collected data

Table 4. Respondents' attitudes about development of rural tourism and its specific types in the area of Trstenik in the future

\begin{tabular}{|c|c|c|c|}
\hline \multicolumn{2}{|c|}{$\begin{array}{c}\text { Do you consider that rural tourism could be } \\
\text { developed in this area in the future? }\end{array}$} & \multicolumn{2}{|c|}{$\begin{array}{c}\text { Do you consider that within rural tourism there } \\
\text { could be developed specific types of tourism } \\
\text { (sport and recreational, cultural, religious...)? }\end{array}$} \\
\hline Yes & No & Yes & No \\
\hline $89,7 \%$ & $10,3 \%$ & $97,7 \%$ & $2,3 \%$ \\
\hline
\end{tabular}

Source: Results based on author's collected data

Results of the research indicate positive attitudes of respondents about rural tourism development in the area of Trstenik in the future. This refers, first of all, on availability 
of natural and anthropogenic potentials for tourism development, as well as favorable geographical position of the municipality (in Table 2 we saw that small number of respondents adduced these elements as limiting factors). Furthermore, even 89,7\% of respondents consider that this part of Serbia has a chance to develop the rural tourism in the future (Table 4). As a confirmation to this information follows a respondents' attitude according to which specific types of tourism such as sport and recreational, cultural, religious, hunting, gastronomic, wine, camping or nautical could be developed at the same time with rural tourism. This is very important for rural tourism development, especially if we bear in mind that tourists of modern age demand active vacation during their stay (Todorović, Štetić, 2009).

\section{Analysis of social networks' impact in the field of (rural) tourism}

This part includes the survey questions with a topic of social networks in the context of (rural) tourism. The usage of social networks is indeed present among the tourists, as shown by information according to which $96 \%$ of respondents are using social networks.

The research involved four social networks: Facebook, Instagram, Pinterest and Trip Advisor. According to extent of usage, the Facebook took the first place, Instagram the second, whereas Pinterest and Trip Advisor share the third place (Table 5).

More than half of respondents $(58,8 \%)$ consider that social networks help partially to their users when receiving the information on the tourism topic is concerned. This result gave us an opportunity to investigate to what extent the respondents are using social networks as means of getting the information (Graph 3). The majority are periodically using social networks for informing in the field of tourism. In order to find out what is attitude of respondents towards impact and importance of social networks in the field of tourism and its promotion, we made two questions: 1) Could the above mentioned social networks have a positive impact on a promotion and an affirmation of rural tourism? (Table 6), 2) If you decided to deal with tourism, would you present your offer through social networks? (Table 6).

Table 5. Extent of social networks' usage among respondents

\begin{tabular}{|l|r|r|}
\hline \multicolumn{1}{|c|}{ Social networks } & $\begin{array}{r}\text { Which of the above mentioned } \\
\text { social networks are you using? }\end{array}$ & $\begin{array}{r}\text { If you are visiting more than } \\
\text { one social network, which of } \\
\text { them in the greatest extent? }\end{array}$ \\
\hline Facebook & $94,1 \%$ of respondents & $78,4 \%$ of respondents \\
\hline Instagram & $52,9 \%$ of respondents & $13,7 \%$ of respondents \\
\hline Pinterest & $17,6 \%$ of respondents & $0 \%$ of respondents \\
\hline Trip Advisor & $17,6 \%$ of respondents & $0 \%$ of respondents \\
\hline
\end{tabular}

Source: Results based on author's collected data

Note: Respondents had a possibility to give more answers on this question 
Graph 3. Frequency of social networks' usage as an information source in the tourism field

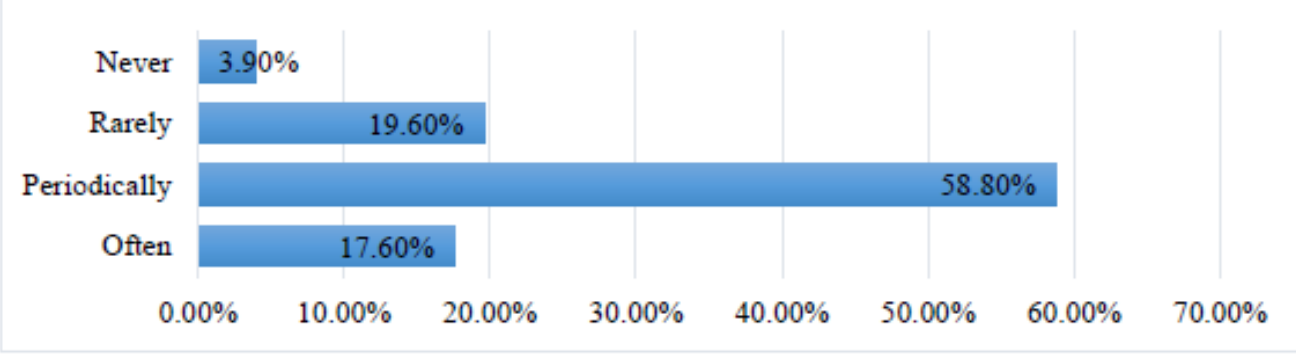

Source: Results based on author's collected data

Table 6. Impact of social networks on a rural tourism promotion and respondents' attitudes about social networks' usage for presenting own tourist offer

\begin{tabular}{|c|c|c|c|}
\hline \multicolumn{2}{|c|}{$\begin{array}{l}\text { Could the above mentioned social networks } \\
\text { have a positive impact on a promotion and an } \\
\text { affirmation of rural tourism in the municipality } \\
\text { of Trstenik? }\end{array}$} & \multicolumn{2}{|c|}{$\begin{array}{l}\text { If you decided to deal with tourism, would you } \\
\text { present your offer through social networks? }\end{array}$} \\
\hline Yes & No & Yes & $\mathrm{No}$ \\
\hline $94,1 \%$ & $5,9 \%$ & $94,1 \%$ & $5,9 \%$ \\
\hline
\end{tabular}

Source: Results based on author's collected data

Table 7. Impact of social networks on a rural tourism promotion (respondents' attitudes per age groups)

\begin{tabular}{|c|c|c|c|c|c|c|c|}
\hline $\begin{array}{l}\text { Could the above mentioned } \\
\text { social networks have } \\
\text { a positive impact on } \\
\text { a promotion and an } \\
\text { affirmation of rural tourism } \\
\text { in the municipality of } \\
\text { Trstenik? }\end{array}$ & & & & & & & $\begin{array}{l}\text { Total } \\
\text { number of } \\
\text { respondents }\end{array}$ \\
\hline Age structure of respondents & $18-21$ & $21-30$ & $31-40$ & $41-50$ & $51-60$ & $\begin{array}{l}\text { o v e } r \\
60\end{array}$ & \\
\hline Yes & 9 & 12 & 13 & 9 & 5 & 0 & \\
\hline No & 1 & 0 & 0 & 1 & 0 & 1 & \\
\hline $\begin{array}{l}\text { Number of respondents per } \\
\text { age groups (absolute values) }\end{array}$ & 10 & 12 & 13 & 10 & 5 & 1 & 51 \\
\hline 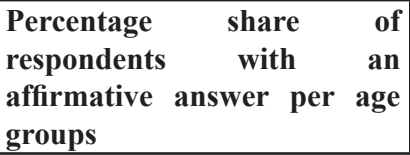 & 17,65 & 23,53 & 25,49 & 17,65 & 9,80 & 0 & \\
\hline
\end{tabular}

Source: Results based on author's collected data 
According to Table 7 we can conclude that the group of respondents which belongs to an age structure from 31 to 40 years mostly considers that social networks would have a positive impact on a rural tourism promotion. Something we have expected and the results are not pointing to is a higher participation of respondents from an age group 41-50 years (in Table 1 we can also notice relatively poor participation of this group of respondents). Why? We were guided by the thought that a vacation in rural area would be necessary to this group of people as a group with alredy formed families and active business engagement. Furthermore, we noticed that a percentage share of these respondents coincide with a percentage share of respondents from 18 to 21 years (Tables 1 and 7). These results leave us a possibility to investigate as follows: should we connect a poor participation of these groups of respondents with their indifference to this type of tourism or it is about other reasons, such as small sample on which a whole research is performed? In order to develop tourism itself, it is important to create an offer in the right way and in order to create an adequate offer, we should know which group of people it would be intended for.

\section{Conclusion}

This research paper has had the aim to perceive all possibilities for rural tourism development in the territory of the municipality of Trstenik. After processing of collected data we have came to the following conclusion: this part of Serbia has a possibility to develop the rural tourism although it is faced currently with a deficiency of accomodation facilities and depleted motivation of local people to be involved in the development process. Social networks, as one of the means for rural tourism promotion, would contribute significantly to that process.

If we want the rural areas of the municipality of Trstenik to find their place on a tourist map, it is necessary to create preconditions for tourism activity development. Tourism, like every other activity, implies first of all existence of human resources, which should utilize natural and anthropogenic potential in an adequate manner. However, the results of the research indicated the lack of motivation of local people and insufficient involvement of local authorities in a direction of rural tourism development (Table 2). The aim is to create a vision and an appropriate strategy which include primarily insight into the rural areas through total potential and limiting factors. Thereafter we should realize the potential effects which rural tourism development would bring and which provide an incentive to local people and local authorities to engage themselves in this activity. Development of this type of tourism would also start up the other specific types of tourism because a geographical position of the municipality and the potentials that it has enable that (Tables 2 and 4).

Directions of further research would also include the following questions: Which group of people would a tourist offer be created for? To what extent rural tourism development would lead to a reduction of unemployment rate and an improvement of a quality of life in the territory of the municipality of Trstenik? How much would that influence the reduction of unemployment rate observed at a state-level? Could rural tourism on the 
territory of the municipality of Trstenik develop itself to the extent to become a model for achieving same results in other places of Serbia? In order to get the answers to these questions, we should broaden the research outside the boundaries of this municipality because an extent of this target group is insufficiently large for a full insight into the topic.

\section{Literature}

1. Ambrosio-Albalá, M., Bastiaensen, J. (2010): The new territorial paradigm of rural development: Theoretical foundations from systems and institutional theories, Institute of Development Policy and Management, University of Antwerp, Antwerp, Belgium (available at: http:/www.ua.ac.be/objs/00251118.pdf , accessed on: 26/12/2017).

2. Cavaye, J. (2001): Rural Community Development-New Challenges and Enduring Dilemmas, The Journal of Regional Analysis \& Policy, vol. 31, no. 2, pp. 111-112, Published online in Journal of Regional Analysis \& Policy (available at: http://www. jrap-journal.org/pastvolumes/2000/v31/31-2-8.pdf, accessed on: 19/2/2018).

3. Cvijanović, D., Mihailović, B., Vukotić, S. (2016): Marketing i konsalting u funkciji razvoja turizma Srbije, Institut za ekonomiku poljoprivrede, Beograd, Serbia.

4. Cvijanović, D., Ružić, P. (2017): Ruralni turizam, Fakultet za hotelijerstvo i turizam u Vrnjačkoj Banji, Univerzitet u Kragujevcu, Vrnjačka Banja, Serbia.

5. Čikić, J., Jovanović, T. (2015): Difuzija znanja i razvoj ruralnog turizma $u$ Vojvodini, Univerzitet u Novom Sadu. Prirodno-matematički fakultet. Departman za geografiju, turizam i hotelijerstvo, Novi Sad, Serbia.

6. Damnjanović, I., Petronić Petrović, L., Tešić, B., Urošević, S. (2015): Informacionokomunikacione tehnologije i održivost u funkciji stvaranja konkurentnog turističkog proizvoda, Synthesis 2015-International Scientific Conference of IT and BusinessRelated Research. doi: 10.15308/Synthesis-2015-566-572, Beograd, Srbija, pp. 566-572 (available at: http://portal.sinteza.singidunum.ac.rs/paper/338 , accessed on: 26/12/2017).

7. Đorđević Milošević, S., Milovanović, J. (2012): Održivi turizam u funkciji ruralnog razvoja. Mala poljoprivredna gazdinstva $i$ ruralni turizam u Srbiji, Fakultet za primenjenu ekologiju Futura. Univerzitet Singidunum. Agroznanje. FAO, Beograd. Vršac. Budimpešta, Serbia. Hungary (available at: http://srpskamagaza.com/doks/ Odrzivi Turizam elektronsko izdanje.pdf, accessed on: 26/12/2017).

8. Đukić, S., Glavaš-Trbić, D., Banjac, N. (2017): Management Problems of Rural Development in Fruška Gora, Economics of Agriculture, vol.64, no.1, pp. 28-35, The Balkan Scientific Association of Agrarian Economists, Belgrade, Serbia, Institute of Agricultural Economics, Belgrade, Serbia, Academy of Economic Studies, Bucharest, Romania (available at: http://www.ea.bg.ac.rs/images/Arhiva/2017/ Broj\%201/2\%20EP\%201\%202017\%201q-2.pdf, accessed on: 26/12/2017). 
9. Maksin, M. (2012): Turizam i prostor, Univerzitet Singidunum, Beograd, Serbia (available at: https://singipedia.singidunum.ac.rs/izdanje/40818-turizam-i-prostor , accessed on: 26/12/2017).

10. Maksin, M., Pucar, M., Korać, M., Milijić, S. (2009): Menadžment prirodnih i kulturnih resursa u turizmu, Univerzitet Singidunum, Beograd, Serbia (available at: $\quad$ https://singipedia.singidunum.ac.rs/izdanje/40920-menadzment-prirodnih-ikulturnih-resursa-u-turizmu , accessed on: 26/12/2017).

11. Markov, S. (2006): Seoski turizam-preduzetnička aktivnost u seoskim područjima iz sociološke perspektive, Naučno-stručni časopis iz turizma. Turizam br. 10. Savremene tendencije u turizmu 2006., no. 10, pp. 42-44, Prirodno-matematički fakultet. Institut za geografiju, turizam i hotelijerstvo, Novi Sad, Serbia (available at: http://www.dgt.uns.ac.rs/turizam/arhiva/turizam10.pdf , accessed on: 26/12/2017).

12. McKercher, B. (2016): Do Attractions Attract Tourists? A Framework to Access the Importance of Attractions in Driving Demand, International Journal of Tourism Research, vol. 19 , pp. 120-122, Published online in Wiley Online Library (available at: http://onlinelibrary.wiley.com/doi/10.1002/jtr.2091/epdf , accessed on: 26/12/2017).

13. Milenković, S., Utvić, S. (2013): The Challenges of Rural Areas in Serbia Promising Tourist Activities, Economics of Agriculture , vol. 60, no. 1, p. 66, The Balkan Scientific Association of Agrarian Economists, Belgrade, Serbia, Institute of Agricultural Economics, Belgrade, Serbia, Academy of Economic Studies, Bucharest, Romania (available at: http://www.ea.bg.ac.rs/images/ Arhiva/2013/Broj\%201\%20-\%202013 \%20Issue\%201\%20-\%202013/5\%20 -\%20Milenkovic,\%20Utvic.pdf, accessed on: 26/12/2017).

14. Njegovan, Z. (2016): Ekonomika turizma i seoskog turizma, Poljoprivredni fakultet. Univerzitet u Novom Sadu, Novi Sad, Serbia.

15. Okazaki, S., Andreu, L., Campo, S. (2016): Knowledge Sharing Among Tourists via Social Media: A Comparison Between Facebook and Trip Advisor, International Journal of Tourism Research, vol. 19, pp. 107-108, Published online in Wiley Online Library (available at: http://onlinelibrary.wiley.com/doi/10.1002/jtr.2091/ epdf, accessed on: 26/12/2017).

16. Popesku, J., Rosić, I. (1999): Ključni aspekti razvoja seoskog turizma Srbije, Ekonomski fakultet. Univerzitet u Kragujevcu, Kragujevac, Serbia.

17. Saravanakumar, M., SuganthaLakshmi, T. (2012): Social Media Marketing, Life Science Journal, pp. 4444-4451 (available at: http://www.lifesciencesite.com/1sj/ life0904/670 13061life0904_4444_4451.pdf, accessed on: 26/12/2017).

18. Sheenan, L., Vargas-Sanchez, A., Presenza, A., Abbate, T. (2016): The Use of Intelligence in Tourism Destination Management: An Emerging Role for DMOs, International Journal of Tourism Research, vol. 18, p. 549, Published online in Wiley Online Library (available at: http://onlinelibrary.wiley.com/doi/10.1002/ 
jtr.2072/pdf, accessed on: 26/12/2017).

19. Stelzner, M.A. (2016): 2016 Social Media Marketing Industry Report: How MarketersAreUsing SocialMediato GrowTheirBusinesses, SocialMediaExaminer, Poway, California, United States (available at: https://www.socialmediaexaminer. com/wp-content/uploads/2016/05/SocialMediaMarketingIndustryReport2016. pdf, accessed on: 26/12/2017).

20. Stojković, M. (2013): Primena društvenih mreža u turizmu i ugostiteljstvu. Priručnik za osnovnu primenu društvenih mreža u promociji i plasmanu turističkougostiteljske ponude, Specijalizovana agencija TMC- Tourism Management and Consulting, Bor, Serbia.

21. Strategija razvoja turizma Republike Srbije za period 2016-2025, Službeni glasnik, Srbija, 2016 (available at: http://mtt.gov.rs/download/3/strategija.pdf).

22. Škorić, D. (2013): Seoski turizam u Srbiji- preporuke za promene u lokalnim zajednicama prema iskustvima iz prakse, SANU, Beograd, Serbia.

23. Štetić, S., Šimičević, D., Ćurčić, N. (2013): Specifični oblici turizma, Snežana Štetić, Beograd, Serbia.

24. Štetić, S., Todorović, M. (2009): Ruralni turizam, Geografski fakultet. Univerzitet u Beogradu, Beograd, Serbia.

25. Tsai, C.T. (2016): Memorable Tourist Experiences and Place Attachment When Consuming Local Food, International Journal of Tourism Research, vol. 18, p. 536, Published online in Wiley Online Library (available at: http://onlinelibrary. wiley.com/doi/10.1002/jtr.2070/epdf, accessed on: 26/12/2017).

26. Valrabenštajn, K. (2007): Uticaj brenda i imidža turističke destinacije na percepciju kvaliteta turističkog proizvoda kod potencijalnih turista, Naučnostručni časopis iz turizma. Turizam br. 11. Savremene tendencije u turizmu 2007., no. 11, pp. 186-187, Prirodno-matematički fakultet. Institut za geografiju, turizam i hotelijerstvo, Novi Sad, Serbia (available at: http:/www.dgt.uns.ac.rs/turizam/ arhiva/turizam11.pdf, accessed on: 26/12/2017).

27. Vojnović, B., Cvijanović, D., Stefanović, V. (2012): Razvojni aspekti turističke delatnosti, Institut za ekonomiku poljoprivrede, Beograd, Serbia. 


\title{
MOGUĆNOSTI RAZVOJA RURALNOG TURIZMA NA PODRUČJU OPŠTINE TRSTENIK
}

\section{Jelena Bićanin ${ }^{2}$}

\begin{abstract}
Sažetak
Povoljan geografski položaj opštine Trstenik, kojaje smeštena u plodnoj dolini Zapadne Morave, omogućio bi lokalnom stanovništvu da se bavi ruralnim turizmom, kome je posvećeno nedovoljno pažnje uprkos potencijalnim pozitivnim efektima koje bi njegov razvoj doneo. Primarni cilj ovog istraživačkog rada bio je sagledavanje potencijala opštine, koji bi doprineli razvoju ruralnog turizma. Istraživanje je sprovedeno u periodu od 20. jula do 2.septembra 2017. godine na uzorku od 138 ispitanika. Za potrebe istraživanja na raspolaganju su bile sledeće metode: kvantitativni pristup ispitivanja javnog mnjenja u vidu anketnih upitnika zatvorenog $i$ anonimnog tipa, metod analize, metod uzorka, kao i metod deskripcije. Rezultati istraživanja su pokazali sledeće: teritorija ove opštine raspolaže potencijalom za razvoj ruralnog turizma uprkos nedostatku smeštajnih kapaciteta i nedovoljnoj motivisanosti lokalnog stanovništva za bavljenje turizmom, a društvene mreže bi mogle pružiti doprinos njegovoj promociji $i$ razvoju. Ograničenje rada se ogleda u malom obimu ciljne grupe ispitanika, što ostavlja mogućnost za proširenje istraživanja van granica teritorije ove opštine.
\end{abstract}

Ključne reči: ruralni turizam, Trstenik, potencijali, promocija, društvene mreže

2 Jelena Bićanin, Doktorand, Univerzitet u Kragujevcu, Fakultet za hotelijerstvo i turizam, Vojvođanska ulica bb, 36210 Vrnjačka Banja, Srbija, Telefon: +381 616809 713, E-mail: jelenabicanin9@gmail.com 